\title{
The Weather Is Changing . . . or Meteorologists and Broadcasters, the Twain Meet
}

\author{
Robert T. Ryan ${ }^{1}$ \\ NBC Television, WRC-TV, Washington, D.C. 20016
}

\section{Introduction and synopsis}

September 10, 1981 marked a first for meteorologists, when several members of the AMS participated in a panel discussion on broadcast meteorology at the annual meeting of the Radio Television News Directors' Association in New Orleans.

Dennis Feltgen, KSTP-TV/AM-FM, Minneapolis, spoke of the progress broadcast meteorology has made over the past 30-plus years, and showed a videotape that traced the evolution of television weather presentations from the chalkboard announcers era, through the clown and "weathergirl" years, to today's professional broadcast meteorologist. Feltgen pointed out how the visual part of the weather program is changing, as more sophisticated television equipment is used. He also emphasized that the best way to serve (and keep) the audience is for competent broadcast meteorologists to interpret the data obtained from this new equipment, and give accurate weather forecasts.

John Graff, MIC NWSFO, Minneapolis, emphasized the need for cooperation between the National Weather Service and the broadcast meteorologist. He, too, spoke of the progress of the science of meteorology and advances in our ability to forecast the weather over the past $20-30$ years. He felt more mention should be made of the NWS, NMC, and NOAA meteorologists who are involved in modeling, climatology, research, etc., and who provide the forecast products necessary to the broadcast meteorologist. He remarked on the appropriations cutbacks pending, and yet to come, and said, "If they (viewers) heard of your NWS colleagues and their programs in the service ... through media cooperation more often ... our, and your, services might be given the aid we both most richly deserve to move ahead together to develop a better forecast model."

\section{Address by R. Ryan}

First, let me thank the National Radio and Television News Directors' Association for the opportunity to participate in this panel. To my knowledge, it is a first for us broadcast meteorologists - I hope it will not be a last.

It is also a unique opportunity for myself, representing an

'Chairman, AMS Board on Broadcast Meteorology.

$0003-0007 / 82 / 030308-03 \$ 04.75$

(c) 1982 American Meteorological Society increasing number of broadcast meteorologists who are holders of the AMS television and radio Seal of Approval, to share with you some of my thoughts, concerns, and outlook for the future. Broadcast meteorology is matching some of the strides in other segments of broadcast journalism; these two fields have much more in common than we might think at first glance. But what is meteorology, and what is a meteorologist?

First, some of the things meteorology is not. Meteorology is not a craft; it is not an art (in spite of what some writers would have us believe); and it is not a guessing game. Meteorology is a science that examines and seeks to understand our atmosphere. It is a science as much as physics, chemistry, biology, or geology, to name a few. It is also the one science that, rather than just examining the past, or measuring the present, seeks to regularly predict the future-a task for which we meteorologists sometimes seem eternally damned.

Imagine a system on a rotating sphere that is 8000 miles wide, consists of different materials, different gases that have different properties (one of the most important of which, water, exists in different concentrations), heated by a nuclear reactor 98 million miles away. Then, just to make life interesting, this sphere is oriented such that, as it revolves around the nuclear reactor, it is heated differently at different locations at different times of the year. Then, someone is asked to watch the mixture of gases, a fluid only 20 miles deep, that covers an area of 250 million square miles, and to predict the state of that fluid at one point on the sphere two days from now. This is the problem weather forecasters face.

Keeping track of this complex system and forecasting its future state is not art, it is a science-a science like any other that involves measurements subject to error, a science subject to an incomplete understanding of the system and, in attempting to predict what will happen in the future, a science subject to errors and mistakes. However, given the complexity of the task that is concerned with something that takes almost 1000 American lives each year and has an impact on the economy of billions of dollars each year, meteorologists do an amazingly excellent job of understanding and forecasting the weather. It is also a task which should not be given to someone who does not know what he or she is doing. Nor should we place someone in a position of responsibility - as someone in the news dissemination area is - who is dealing with a complex science that has a major impact on peoples' lives, who does not know what he or she is doing, who does not know anything about the subject, or worse, who knows just enough to get him or herself into trouble. 
The NWS forecast, prepared by their competent, professional meteorologists, can be read by anyone-just as anyone can read the AP or UPI wire copy. But I think we all agree that broadcast journalism is well beyond the days of simply reading wire copy; it is obvious that it is time to fully utilize broadcast meteorologists to interpret, illuminate, educate, and explain what is a complex science.

Broadcast journalism is proud of its growth and maturity in having competent journalists as news anchors and reporters, business reporters who have a background in economics, legal correspondents who may be lawyers, and consumer staffs; and it seems to me a science that has an impact on our nation of billions of dollars each year, is often a major news story, and in its violent form takes 1000s of lives should be reported by someone who knows what he or she is doing-a professional broadcast meteorologist.

As more professionals are placed in increasingly diverse areas of broadcast journalism, I continue to be amazed that there are those who feel that the weather report is the logical place for a comic strip.

But, what is a professional meteorologist? There are no state or national licensing boards as in medicine or engineering, and no magic piece of paper that says this person is a meteorologist, any more than there is a magic piece of paper that says this person is a journalist. It is fair to say that it is generally accepted that a meteorologist is someone who has, as a minimum, his or her bachelor's degree in meteorology or a related physical science_-or equivalent training — and has been working in some facet of the atmospheric sciences for a number of years.

There are about 100 colleges and universities across the country that offer baccalaureate and advanced degrees in meteorology, and a number of colleges now offer some preparation in broadcast meteorology - which leads me to the American Meteorological Society and its Seal of Approval program.

The American Meteorological Society is the scientific society of meteorologists. The Society's objectives, as stated in its constitution, are the "development and dissemination of knowledge of meteorology in all its phases and applications and the advancement of its professional ideals." The Board of Radio and Television Weathercasting, ${ }^{2}$ which consists of seven experienced broadcast meteorologists (of which I am the present Chairman), was formed in 1957. Its purpose is to establish criteria for the evaluation of radio and TV weathercasts, and to recommend to the AMS those applicants for the Seal of Approval whose presentation meet high standards of 1) informational value, 2) audience interest, 3) educational value, and 4) professional attitude.

The overall purpose of the seal program is to recognize minimum professional standards of competence in men and women broadcasting weather information. From 1960 to 1972 , the seal was granted only to professional meteorologists. Since 1972 , the seal could also be obtained by nonprofessionals who had a minimum of five years' experience broadcasting the weather and had also passed a rigorous exam administered by the AMS that tests competence and the ability to maintain the high standards of the seal program.

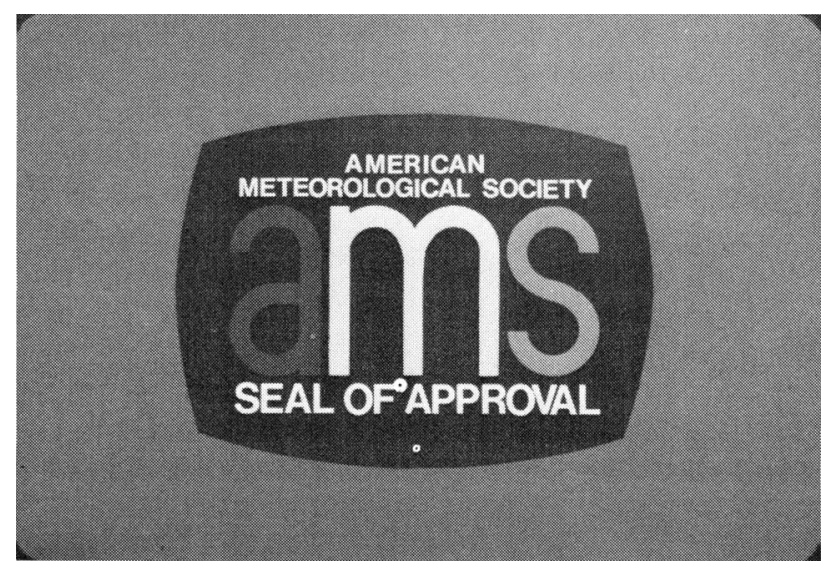

FIG. 1. AMS Seal of Approval

This is what the AMS seal looks like (Fig. 1). The first seal was awarded in 1960 and there are now more than $220 \mathrm{TV}$ seals and almost 100 radio seals held by individuals. There is no question that the AMS seal is gaining acceptance and is coming to be recognized as a minimum standard of professionalism and competence for a weather reporter. This graph (Fig. 2) shows the number of seals granted over the years. The trend is clear, with more seals being granted each successive year.

I should point out that just because an applicant may be a meteorologist, even with an advanced degree, that does not mean he or she automatically will be granted the seal. He or she must be able to communicate his or her knowledge in a professional, coherent, and interesting way, and know how to use some of the tools of our profession. These tools include color radar, GOES pictures, computer data terminals, graphics, and maps.

As broadcasters and meteorologists, we can be proud of the job we are doing, but there is still much we can do to upgrade our reports and presentations. One way this can be done is for as many meteorologists as possible to obtain the

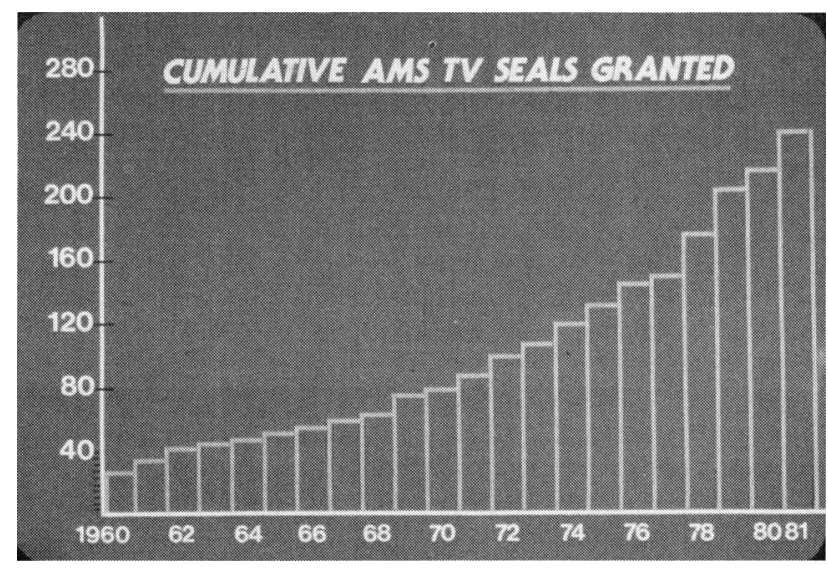

FiG. 2. Cumulative number of Seals granted, 1960-81.

${ }^{2}$ Now called the Board on Broadcast Meteorology. 
AMS seal. The success of the seal program partially depends on the station management and the general public knowing more about what the seal is and what it means. The AMS Board plans to institute a new procedure so that when an applicant is granted the seal, a news release is sent from AMS headquarters to the local print media. At the same time, a letter of congratulation would be sent from the current AMS president to the station management. This year, we also plan to institute a seal re-evaluation process to keep our professional standards and level of competence high.

Few subjects are more timely and can better serve the public, at times of dangerous weather, than competent, thorough, and accurate reporting of the weather. Few subjects lend themselves better to the immediacy of television and radio. In the years to come, we will see more sophisticated equipment for the broadcast meteorologist. Equipment such as Doppler radar (which Dennis already has), high resolution color satellite images, animated weather maps, and computer graphics are useful tools to the meteorologist. They are also useful to the viewing audience, who will be able to better understand and know about a crucial element of their world and lives. But bear in mind that it is not the equipment that will attract and serve the audience, but the competent person who knows his or her subject, knows what he or she is doing, and knows how to use the latest equipment to best accomplish the task of a broadcaster and scientist. I believe that person to be the professional broadcast meteorologist who has the AMS Seal of Approval.

A scientist, a communicator-yes, a personality-but foremost someone who is trained for what he or she is doing, takes his or her responsibility seriously, and can communicate the vital information to the viewer or listener clearly and concisely - this is a broadcast meteorologist, a broadcast journalist.

Again, my sincere thanks for the opportunity to address this group.

\section{Conclusion}

Meteorology is the one science that directly affects peoples' lives each and every day. It is also the one science that historically has been the brunt of endless jokes. Whether we as meteorologists like it or not, the public's image of our science and of us as scientists is, to a large extent, determined by what it sees and hears during the daily television and radio report, which, for the overwhelming percentage of Americans, is their source of weather information. In many cities across America, meteorology is often represented by people who know nothing of the science but who are "weathermen," just as, in the average person's eye, any eminent Member or Fellow of the AMS is a "weatherman."

If we are to continue to grow and progress as a science, and a professional society of scientists, it is vitally important for the public to have a positive professional image of weather forecasters and some understanding of the state of our science. More and more cutbacks in scientific funding seem assured in the future. Without public awareness of who meteorologists are and what meteorology is, we will all suffer.

It is vitally important that all meteorologists, other concerned scientists, and individuals who recognize the great strides we have made and the hurdles we face in the future, actively support professionalism and dedicated professionals in broadcast meteorology.

As broadcast meteorologists, we have the obligation to see that the work, research, and vital support of so many scientists behind us are given credit and publicity. In addition, we also need the active support of those we represent.

Ben Franklin, one of our own breed, perhaps put it best when he said, "We must all hang together, or assuredly we shall all hang separately." The occasion was the signing of the Declaration of Independence. It might well apply to a meeting of AMS members of diverse interests who share common goals in fiscally austere times.

\section{announcements (continued from page 307)}

government, industry, and university laboratories in several defenserelated industries, especially microelectronics and materials research, is likely to increase, as will international cooperation on space and high-energy physics research.

Among those areas of science and technology that are likely to affect American society and its problems relatively soon, the report cites:

Robotics and artificial intelligence, which, together with research on very high speed integrated circuits, will have impact on industrial manufacturing processes and on the next generation of intelligent military systems;

Materials science, which by developing stronger, lighter, more heat-resistant materials from domestic raw materials will affect national defense, the aeronautics industries, and eventually other U.S. industries;

The Space Shuttle, which will offer a wide range of opportunities for astronomical studies, remote sensing of Earth, materials processing techniques, and other activities;

Remote sensing satellites, which will provide information about renewable and nonrenewable natural resources and residential development patterns valuable to both the public and private sectors;
Recombinant DNA and other genetic engineering research, which will influence all the life sciences through new vaccines and drugs, improvements in agricultural crops, and new methods of animal husbandry;

Information sciences, which will produce better ways of storing and retrieving immense amounts of information and which will improve analytical tools used to assess, compare, and manage risks for developing regulations and for evaluating the costs and benefits of alternative regulatory strategies or alternate classes of products or processes, such as energy technologies; and

Electronic technologies, which, using results from the cognitive and behavioral sciences, will provide better training methods for military personnel, for the continuing education of scientists and engineers, and for students at all levels.

Copies of the Five Year Outlook on Science and Technology 1981 and the two Source Volumes are available from the Superintendent of Documents, Government Printing Office, Washington, D.C. 20402 